\title{
性別，年代差からみた作業負荷量に対する 循環機能の特徵*
}

徳田哲男 ${ }^{* *}$, 丸山仁司 ${ }^{* * *}$, 秋山純和 ${ }^{* * *}$, 中山彰博 ${ }^{* * *}$, 池谷義道 ${ }^{* * *}$, 高島 耕 ${ }^{* * * *}$

The purpose of this study was to clarify the effects of sex and age on the circulatory function characteristies to the bicycle ergometer. The work load $(20,40$, and 60 watts) was set up in order to approximate three levels of the daily work load. The subjects were 9 aged, 20 middle aged, and 26 young adult persons (both males and females). Measurements of circulatory function to the exercises were made for 1) oxygen intake ; 2) heart rate ; and 3) blood pressure.

Heart rate and systolic blood pressure indicated remarkable differences in terms of sex and age with an increase in work load, and the highest values on these physiological measures were shown by the aged women. It was also noted that the aged mens' response to the 60 -watt exercise was characterized by a smaller increase in oxygen intake in comparison with that of the middle aged men. In order to determine the major cause of the smaller increase in oxygen intake on the part of aged men, we examined the increase and recovery of their heart rate, metabolic rate, pressure rate product, and oxygen pulse. The 60-watt work load was thought to be near the maximum level of circulatory function for the aged men.

自転車エルゴメータにより，日常活動で経験する程度の作業量（20，40，60 watts）に対する循環機 能の特徵を性別，年代別に分けて検討した，老年者 9 名, 壮年者20名, 若年者 26 名を対象とし，1）酸 素捸取量，2）心拍数，3）血圧を測定した。 心拍数, 最高血圧はともに作業量の增加に伴い性差, 年 代差が検出され，老年女性が最も高い反応結果を示した． 60 watts 負荷で老年男性の酸素摄取量の増加 速度に低下が認められた。この原因を把握するために心拍数初期上昇率おょび回復率, Mets 值, 心筋 酸素捸取量予測值，酸素脈などから検討を加えた。この作業量は老年者の循環機能許容範囲の上限に近 い水準であることがうかがえた。

\section{1. はじめに}

\section{身体に各種のストレスを課し，てれによる生体内の各}

* 昭和 57 年 2 月 13 日受付

** 東京都老人総合研究所 Tokyo Metropolitan Institute of Gerontology.

*** 東京都板橋ナーシングホーム Tokyo Metropolitan Itabashi Nursing home.

**** 東京都養育院付属病院

Tokyo Metropolitan Yoikuin Hospital.
レベルで発生する複合化された生体応答を, 力学, 運動 学, あるいは運動生理学的手法を用いて多角的側面から 捉える研究が報告されており，運動負荷に対して生体が もつ特有な生理的反応機序の解明が武みられてきた。そ こには段階的に負荷量を増し，ついには all out にまで 追い込むことで, 対象者の最大能力の推測を試みる知見 も多い4). また最近一段とブーム熱が高まってきたジョ ギングなどにみられるような, 銭練効果を目的とした個 人の至適運動負荷量の強度, 持続, 頻度の関係を推定す る報告》も見受けられる。乙れら一連の研究報告から， 
負荷量の変化とてれによる生体応答を定量的に捉えた各 種の生理指標の間には，かなり高い相関が認められてい $3^{13,14)}$ 。しかし，研究に採用される実験対象者の多くは 学生など若年者が中心であり，提示される負荷強度も日 常活動で経験する作業内容などに比べて著しく強い場合 が多い，中高年粭者の日常活動や就労時でみられる程度 の作業量に対する生理的反応を推定する場合には，前述 した実験方法のもとで得られた研究成果の延長線上に， 中高年齢者の反応結果も位置しうるか否かが問 題とな る. ところが老化化伴う筋・神経系の変性など16) によ り，ストレスに対して適切に対応する生体内部の恒常性 維持機構の減退が認められ，直接には若年者に上る既存 の研究成果を活用しにくいのが実情である.

本研究では, 就学時あるいは日常生活で体験する程度 の作業強度を, 電気ブレーキ式自転車エルゴメータによ り負荷し，てれによる高年齢者の生理的反応特性の把握 を目的とした. 加賀谷 ${ }^{8}$ は主婦の日常家事作業の心拍数 を測定し，100 拍以上に上がることは少なく, 120 拍以上 はほとんどなかったとしている，作業強度の上限設定は 心拍数が 100 110 拍まで上がるととを目標に， 60 watts を上限負荷強度とした。

\section{2. 実 験}

\section{2-1. 测定指標}

酸素摄取量の測定方法はマスク式，マウスピース式， フード式などに大別されるが，連続測定が可能なとと や，運動中であっても被験者の表情を観察しやすいとい う点から,フード式の Metabo Auto Dilute MAH 606 （フクダ産業製）を採用した。

心拍数はテレメータ方式（三栄測器製）により行っ た。電極位置は動作中でのアーチファクトの混入による 波形のゆれが少ない場所として, 胸骨体中央部（陽性） および右鎖骨中央部に使い捨て電極により接着 固定し た.

血圧測定はデジタル血圧計のアイヘルスデジタル 8000 （ウエダ眮業製）に上り行った. 被験者の測定肢右上腕 部はあらかじめ心倵の高さに設定した肘かけ台の上に軽 く乗せ，上肢はできる限りリラックスした状態に維持す るととで, 作業中であっても30秒間隔で血圧の判読を可 能とした。

\section{2-2. 測定手順}

歩行運動のような日常頻繁に行っている動作と比較し
て, 自転車による運動は老年者で経験の少ない者が多数 見受けられたととから，測定に先立ち自転車試乗による 習熟を実施した。被験者は食後 2 時間以上経過の後, 椅 座位安楽姿勢で安静開始時および 5 分経過後の心拍数, 血圧を各々 3 回測定した。次に自転車に乗車し, 酸素摂 取量の測定を開始すると同時に, 椅座位の場合と同様な 方法で心拍数，血圧の測定を行った．作業および回復期 間の心拍数と血圧の測定は, 作業開始より 30 秒間隔で間 欠的に測定した. 酸素摄取量は自転車乗車から実験終了 までの全期間を連続的に測定した。

作業順序は最も弱い 20 watts 負荷から開始し, 各負 荷の間には 5 分間の回復期間を挿入し，40, 60 watts と 負荷強度を増加させた. 各作業の持続時間は 5 分間, ペ タルの回転数は $40 \mathrm{rpm}$ と指定した. 実験開始から終了 までの被験者拘束時間は40〜50分間であった。

\section{2-3. 作業中止の基準}

老年者はストレスに対して呼吸・循環機能面での適応 範囲が若年者に比べて著しく制限されておりり，ててで 設定した程度の作業量であっても，老年者の安全性につ いては十分な配慮が必要である，そてで諸家3,11の研究 報告を参考に，老年者が作業を行う場合に特注意を必 要とする点を検討し，作業中止の基準（表 1）在作成し た。この基準に基づき各作業虏果施した。

\section{2-4. 被験者の属性}

日常活動に身体的支障の認められない男女を年代別 （若年層 $20 ， 30$ 歳代，壮年層 $40 ， 50$ 歳代, 老年層60歳以 上）に採用し，作業中止の基準に基づき測定を行った。 老年風は板橋老人ホーム居住者であり, 過去の生活歴の 個人差は大きいものの, 現在の生活構造は類 似してお りほほとんどの者が散歩など軽い運動を日課とするな ぞ, 活動的な日常生活を送っているとみられる老年者で あった。若年, 壮年者は東京都養育院内の睵員 (研究員, 看護婦など）を対象とした。若年，壮年㐿は全員が60 watts 負荷まで達成可能であったのに対して，老年風は 男女それぞれ15名を測定対象として予定したが，(1)臥床 安静で絶対性不整脈が発現した男性 1名, (2)測定前の自 転車習熟過程（20 watts 負荷で $40 \mathrm{rpm）で} 5$ 分間の作業 が困難と判断された男性 1 名, 女性10名，(3)男性は60 watts 負荷，女性は40 watts 負荷（女性は60 watts 負荷 が全員不可）がそれぞれ達成できなかった男性 6 名，女 性 2 名なぞ，測定した老年者全体の77\%の者が 60 watts 負荷が不可能であった．とのため表 2 で示すように，老 年男性は60 watts 負荷が達成できた者 6 名（他 1 名は酸 
表 1 作業中止の基準

Tab. 1 Guidelines for signs and symptoms of exertional intolerance.

\begin{tabular}{|c|c|c|}
\hline 区 間 & 的 & 基準とした主要な項目 \\
\hline 作 業 前 & $\begin{array}{l}\text { 目標とする上限負 } \\
\text { 荷強度を設定 }\end{array}$ & $\begin{array}{l}\text { 1. カルテによる呼吸・循環系疾患の有無 } \\
\text { 2. 安静時心電図による不整脈の検討 } \\
\text { 3. ペタルの回転などから作業に対する習熟度の観察 }\end{array}$ \\
\hline 作 業 中 & $\begin{array}{l}\text { 作業の終了を待た } \\
\text { ずに中止 }\end{array}$ & $\begin{array}{l}\text { 1. 標的心拍数への到達および不整脈の頻発（予測最高心拍数の } 85 \% * \text { ) } \\
\text { 2. 最高血圧が } 230 \mathrm{mmHg} \text { 程度に達する } \\
\text { 3. } \text { 下肢動作の緩慢化, 体幹動摇の増大など } \\
\text { 4. 目がうつろ, 顔面蒼白など } \\
\text { 5. 作業に対する不満および痛み, 息苦しさなど苦痛の申告 }\end{array}$ \\
\hline 作 業 後 & $\begin{array}{l}\text { 次の作業に対する } \\
\text { 実施の判断 }\end{array}$ & $\begin{array}{l}\text { 1. 作業終了直後から } 1 \text { 分以上にわたって酸素摂取量の低下がみられない. } \\
\text { あるいは作業中に比較して高い酸素負債を継続して記録 } \\
\text { 2. 不整脈の頻発 } \\
\text { 3. } \\
\text { 3. 観報告による検討** }\end{array}$ \\
\hline
\end{tabular}

* 予測最高心拍数 : 20 嵅の最高心拍数を 200 拍, 年間 0.7 拍ずつの減少として算出

** 作業終了後の主観的作業強度2)で「かなりきつい作業」と答申

表 2 被験者の属性

Tab. 2 Physiological characteristics of the subjects.

\begin{tabular}{l|l|c|c|c|c|c|c|c}
\hline \multirow{2}{*}{ Sex } & \multirow{2}{*}{ Group } & \multirow{2}{*}{$\begin{array}{l}\text { Number } \\
\text { of subj. }\end{array}$} & \multicolumn{2}{|c|}{ Age (yrs) } & \multicolumn{2}{c|}{ Height (cm) } & \multicolumn{2}{c}{ Weight $(\mathrm{kg})$} \\
\cline { 4 - 9 } & & MEAN & S.D. & MEAN & S.D. & MEAN & S.D. \\
\hline \multirow{3}{*}{ Men } & Young & 13 & 28.6 & 4.6 & 170.0 & 3.6 & 60.3 & 4.9 \\
& Middle & 9 & 46.7 & 6.0 & 163.3 & 4.7 & 62.9 & 8.8 \\
& Elderly & 6 & 69.8 & 4.4 & 160.5 & 6.8 & 52.0 & 9.8 \\
\hline \multirow{3}{*}{ Women } & Young & 13 & 28.9 & 5.1 & 154.4 & 3.5 & 52.6 & 5.1 \\
& Middle & 11 & 47.2 & 4.6 & 152.0 & 6.1 & 51.3 & 6.7 \\
& Elderly & 3 & 67.0 & 3.5 & 144.7 & 6.7 & 44.3 & 12.9 \\
\hline
\end{tabular}

素摂取量の測定不備のため分析から削除), 老年女性は 40 watts 負荷が達成できた者 3 名を分析対象とした。ま た，対象外とした老年者については後日足踏み動作を追 試し，身体機能上の問題点を検討したが，本論文からは 割愛した。

\section{2-5. 分析方法}

一般に作業強度が 弱い場合には定常状態が 成立しう る ${ }^{17)}$ という前提から，当作業においても定常状態の成立 をもって作業負荷量に対する測定指標の反応值とした。 図 1 は安静 (乗車 5 分後の測定値), および各作業負荷に 対する酸素摂取量, 心拍数, 血圧の変動を, 若年男性と 老年男性について比較した一例である．作業開始からの 変化を測定指標間で比較すると, 心拍数は比較的早く定 常状態に到達し，酸素摂取量が最も遅いようであった。
そこで酸素摂取量の定常状態が成立した時点から作業終 了直前までを，各測定指標とも定常状態が成立した期間 とみなし，乙の期間内の加算平均值をもって作業に対す る反応值とした. 定常状態の成立基準は Morehouse ${ }^{11}$ の報告を参考に, 連続する 3 回の測定值の差が $5 \%$ 以内 であるととを原則とし，とれに該当しない場合は作業終 了直前の反応値を採用した.

\section{3. 結 果}

\section{3-1. 各測定指標の年代別, 性別比較}

各測定指標について年代, 性別の平均值および標準偏 差を算出した（表 3 ).

男性の心拍数は作業強度が増加しても年代差が認めら 


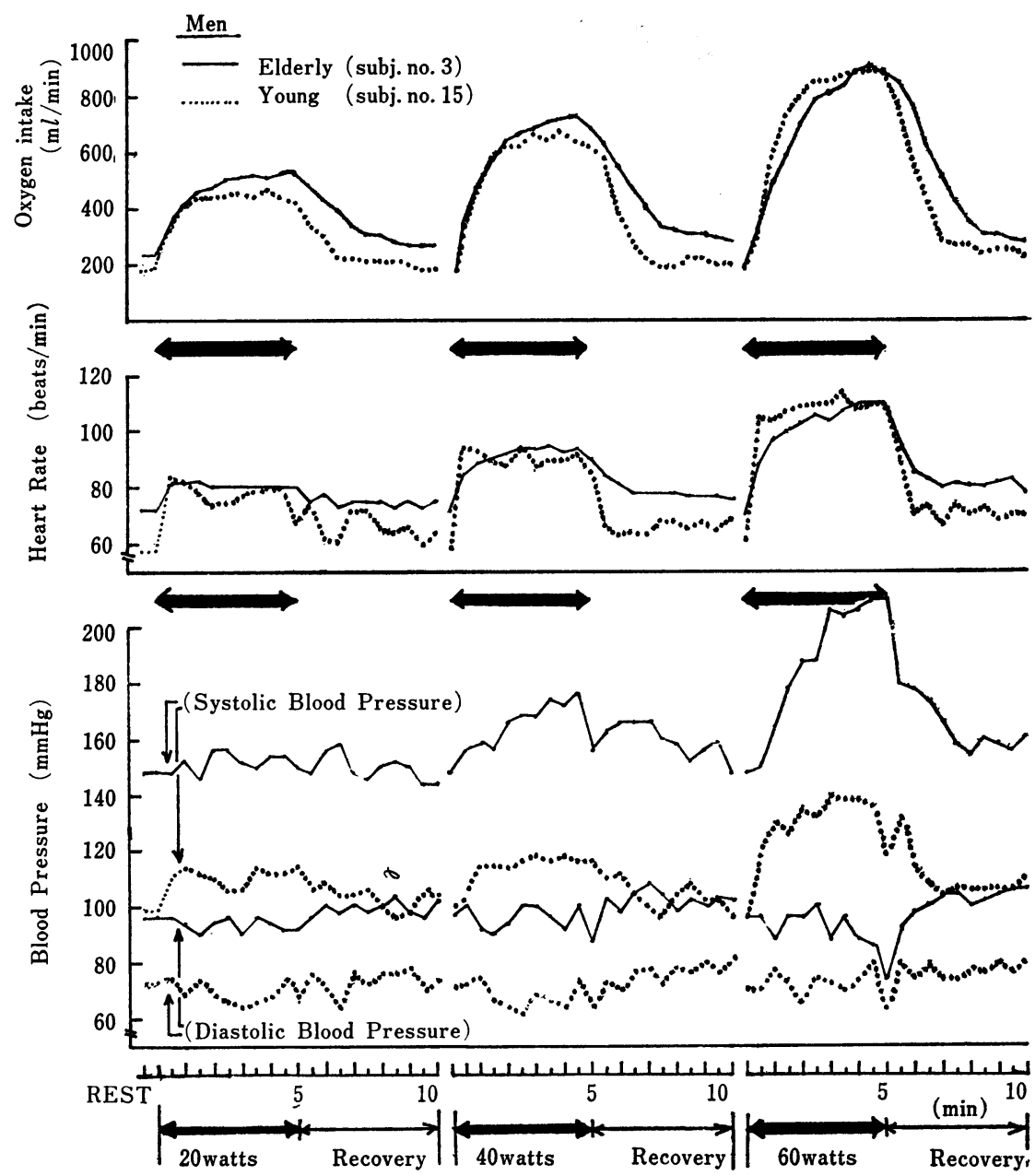

図 1 各作業および回復期間の酸素捸取量, 心拍数, 血圧の測定例

Fig. 1 The change of oxygen intake, heart rate, and blood pressure during work and recovery at the differents work loads on the two subjects.

れないのに対して，女性は老年凮の上昇が著しく，他の 2 層との間に有意な差（ $\mathrm{p}<0.01 ）$ が検出された．同年 代の男女を比較すると女性のほうが高い傾向にあり，60 watts 負荷ではいずれの年代層とも有意 $(\mathrm{p}<0.01)$ で あった。

最高血圧は各負荷とも老化による増高がみられるが， 負荷の変化に伴い性差が観察された。すなわち，安静お よび負荷が弱い段階では男性が，しだいに強くなるに従 い女性が，それぞれ高い傾向を示した。ししかし老年層だ けは各負荷とも女性のほうが常に高く有意 $(\mathrm{p}<0.01)$ であった．老年女性の最高血圧は心拍数と同様に性別， 年代別のそれぞれで最高值を記録した。

安静での体重当たりの酸素摂取量は年代別，性別とも
差が認められないが, 負荷の増加により壮年, 老年層の 増加速度は若年層に比べて著しく, 40 watts 負荷で老年 男性と若年男性, 60 watts 負荷で壮年女性と若年女性に 差（いずれも $\mathrm{p}<0.05 ）$ が検出された. しかし老年男性 は60 watts 負荷で増加速度が鈍り，若年男性の水準とほ ほ等しくなった. 同年代の性差については, 各負荷とも 女性のほうが高い傾向にあり，60 watts 負荷で壮年層に は差（ $\mathrm{p}<0.05 ）$ が検出された.

標準偏差について比較すると, 安静時の酸素摂取量と 心拍数は老年層が最も狭いものの, 負荷が強くなるに従 って老年層の個人差は他の 2 層に比べて拡散する傾向に あった. しかし，老年層の最高血圧は弱い負荷の段階で すでに飽和状態に近いためか, 負荷強度が増しても個人 
表 3 性別, 年代別による酸素摂取量, 心拍数, 血圧の測定結果

Tab. 3 Effects of sex and age on the oxygen intake, heart rate, and blood pressure.

\begin{tabular}{|c|c|c|c|c|c|c|c|c|c|c|}
\hline \multirow{2}{*}{$\begin{array}{c}\text { Direct } \\
\text { Measurements }\end{array}$} & \multirow{2}{*}{ Sex } & \multirow{2}{*}{ Group } & \multicolumn{2}{|c|}{ Rest } & \multicolumn{2}{|c|}{20 watts } & \multicolumn{2}{|c|}{ 40watts } & \multicolumn{2}{|c|}{60 watts } \\
\hline & & & MEAN & S.D. & MEAN & S.D. & MEAN & S.D. & MEAN & S.D. \\
\hline \multirow{6}{*}{$\begin{array}{l}\text { Oxygen } \\
\text { intake } \\
\qquad(\mathrm{ml} / \mathrm{min})\end{array}$} & \multirow{3}{*}{ Men } & Young & 240 & 28 & 483 & 32 & 668 & 27 & 894 & 28 \\
\hline & & Middle & 234 & 25 & 500 & 41 & 713 & 46 & 986 & 44 \\
\hline & & Elderly & 193 & 26 & 453 & 42 & 636 & 54 & 748 & 75 \\
\hline & \multirow{3}{*}{ Women } & Young & 201 & 27 & 466 & 42 & 643 & 36 & 858 & 45 \\
\hline & & Middle & 196 & 28 & 490 & 46 & 670 & 56 & 911 & 44 \\
\hline & & Elderly & 168 & 14 & 396 & 79 & 567 & 117 & - & - \\
\hline \multirow{6}{*}{$\begin{array}{l}\text { Heart Rate } \\
\text { (beats/min) }\end{array}$} & \multirow{3}{*}{ Men } & Young & 73 & 10 & 83 & 8 & 92 & 8 & 103 & 7 \\
\hline & & Middle & 71 & 14 & 84 & 13 & 93 & 15 & 106 & 15 \\
\hline & & Elderly & 64 & 6 & 76 & 8 & 89 & 11 & 105 & 13 \\
\hline & \multirow{3}{*}{ Women } & Young & 76 & 8 & 96 & 9 & 107 & 8 & 125 & 11 \\
\hline & & Middle & 71 & 8 & 90 & 11 & 105 & 8 & 128 & 14 \\
\hline & & Elderly & 87 & 1 & 121 & 14 & 145 & 15 & - & 一 \\
\hline \multirow{6}{*}{$\begin{array}{l}\text { Systolic Blood } \\
\text { Pressure } \\
\qquad(\mathrm{mmHg})\end{array}$} & \multirow{3}{*}{ Men } & Young & 104 & 10 & 117 & 11 & 124 & 10 & 139 & 13 \\
\hline & & Middle & 122 & 20 & 135 & 23 & 144 & 21 & 162 & 27 \\
\hline & & Elderly & 124 & 17 & 149 & 13 & 165 & 13 & 192 & 18 \\
\hline & \multirow{3}{*}{ Women } & Young & 96 & 12 & 108 & 16 & 119 & 16 & 141 & 19 \\
\hline & & Middle & 104 & 12 & 127 & 20 & 147 & 27 & 174 & 27 \\
\hline & & Elderly & 151 & 23 & 200 & 39 & 215 & 25 & - & - \\
\hline \multirow{6}{*}{$\begin{array}{l}\text { Diastolic } \\
\text { Blood } \\
\text { Pressure } \\
\qquad(\mathrm{mmHg})\end{array}$} & \multirow{3}{*}{ Men } & Young & 75 & 10 & 74 & 11 & 69 & 15 & 69 & 16 \\
\hline & & Middle & 89 & 14 & 90 & 14 & 86 & 15 & 88 & 16 \\
\hline & & Elderly & 78 & 12 & 82 & 8 & 82 & 12 & 91 & 10 \\
\hline & \multirow{3}{*}{ Women } & Young & 76 & 10 & 76 & 15 & 76 & 14 & 80 & 15 \\
\hline & & Middle & 78 & 12 & 82 & 14 & 80 & 14 & 79 & 20 \\
\hline & & Elderly & 89 & 15 & 84 & 21 & 71 & 16 & - & - \\
\hline
\end{tabular}
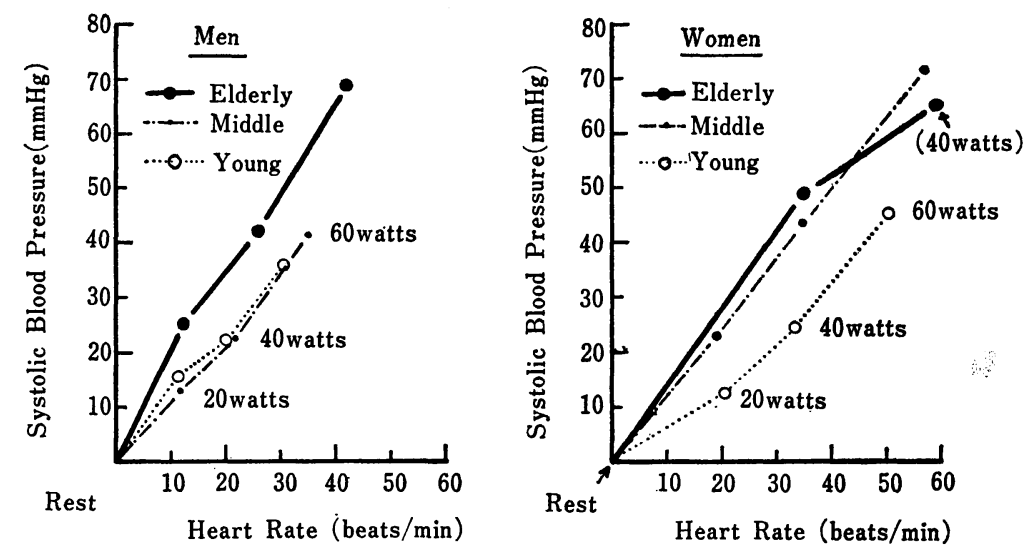

図 2 心拍数と最高血圧との関係 (安静からの増加数)

Fig.2 The relationship between heart rate and systolic blood pressure (Increase from rest period). 


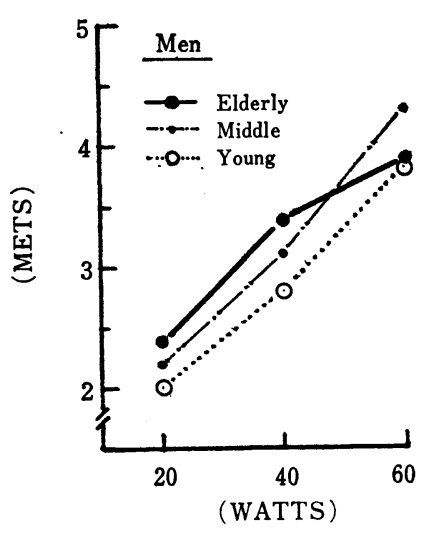

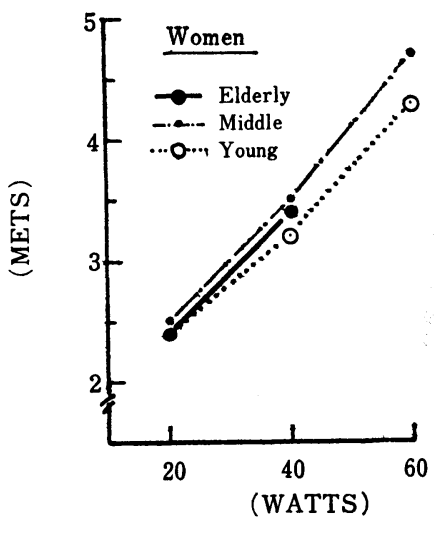

図 3 Watts と Mets の関係

Fig. 3 The relationship between Watts and Mets (metabolic rates).
差は広がらず, むしろ若年, 壮年㐿の標準偏差のほうが 拡散した。

\section{3-2. 心拍数と血圧の関係（図 2)}

心拍数と最高血圧について各作業でとに安静からの增 加数を算出し, 年代, 性別比較を行った. 男性の心拍数 は各作業強度とも年代差が認められないのに対して, 最 高血圧は老年層の增高が著しく, 他の 2 風との間に有意 な差（40, 60 watts ともそれぞれ $\mathrm{p}<0.01 ）$ が検出され た。一方, 女性では男性以上に最高血圧の増高が行われ るが, 老年女性の最高血圧は安静の段階から相 当に高 く, 20 watts 負荷で老年凮と若年, 壮年風には差（いず れも $\mathrm{p}<0.01$ ）が検出された. しかし40 watts 負荷にい たると老年層の最高血圧の増高には限界がうかがわれ， 壮年凮との差は消失した．乙れに対して心拍数は 20,40 watts のいずれの負荷とも老年女性の増加は著しく, 他 の 2 傀との間に差 $(\mathrm{p}<0.01)$ が検出された。 てのよう に作業強度の増加に対する心拍数と最高血圧の反応は, 年代差および性差により異なった変化を示した。

\section{3-3. Watts と Mets の関係（図 3)}

老化による身体諸機能の低下を予測しつつ年代別, 性 別比較を行うには，負荷の絶対量を取り扱う機械的負荷 とともに，負荷を受ける被験者間の身体作業能力が平等 となるように配慮された相対的負荷量についても考虑す る必要がある. これを機能的負荷と仮称し，機械的負荷 を watts 単位, 機能的負荷を Mets 単位（作業中の酸素 䎼取量/安静時の酸素摂取量）として年代比較を行った。 たとえば男性について比較すると，老年首の40 watts 負 荷は3. 4 Mets 程度に相当するが，ての Mets 值で若年層 は50 watts 前後にまで達する. Mets を負荷を受ける側 の “つらさ”の指標とみなすと, 40 watts の機械的負荷
をての両層に課しててを機能的負荷に変換して推測す ると，老年風は若年風の1.2 1.3倍 “つらい”ととがう かがい知れる. しかし，負荷がさらに増加し60 watts に 達すると, 老年風で酸素摂取量の増加量に低い者が認め られ，壮年凮が最高の Mets 值を記録した。そこで60 watts 負荷の段階で老年男性の酸素摂取量の増加速度が 鈍化した理由を把握するため, 対象を男性のみにしほ り，以下の分析を行った。

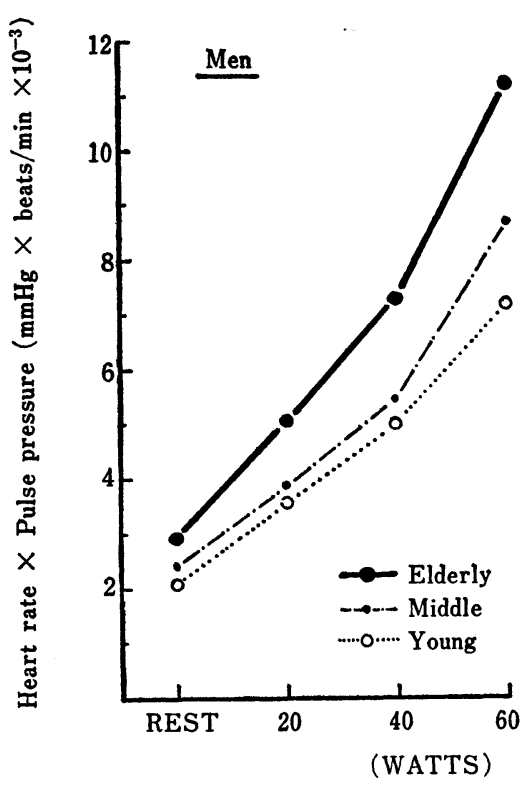

図 4 作業負荷量と心筋酸素摂取量推測指標 （心拍数 $\times$ 脈圧）の関係

Fig. 4 The relationship between work load and pressure rate product (heart rate $\times$ pulse pressure). 


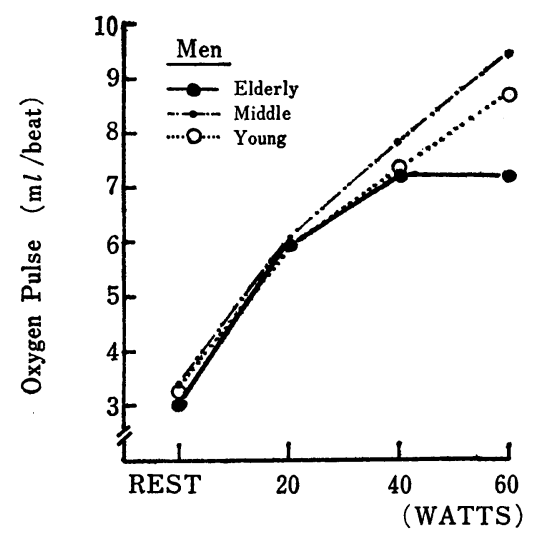

図 5 作業負荷と酸素脈との関係

Fig. 5 The relationship between work load and oxygen pulse.

\section{（1）心筋酸素摄取量の推测（図 4)}

心拍数と脈圧の積により, 心筋酸素捸取量 を推測し た. 安静時では老年層が若干高い傾向にあるものの, 年 代差は認められない. しかし負荷の増加とともに老年層 で急速な上昇がみられ，60 watts 負荷での心筋酸素捸取 量の推測值は老年, 壮年, 若年の順で高く, 老年層と若 年層には差（ $\mathrm{p}<0.01 ）$ が検出された. この心筋酸素摂 取量推測值による結果と, 60 watts 負荷で老年層の酸素 摄取量の増加量が鈍化した結果とは矛盾する内容であ る. このととは, 60 watts 負荷であっても老年凮の心拍 数および血圧の応答特性は 5 分間の作業期間内に定常状 態へ到達するのに対して, 酸素捸取量の応答速度は心拍 数などに比べて遅い傾向にあり（機械的特性を含む，老 年層は酸素捸取量の定常状態の成立を待たずに 5 分間の 作業を終了してしまったてとがうかがえる。

（2）酸素脤（図 5 ）

最大酸素脈は持久性能力を知るうえで適切な測定指標

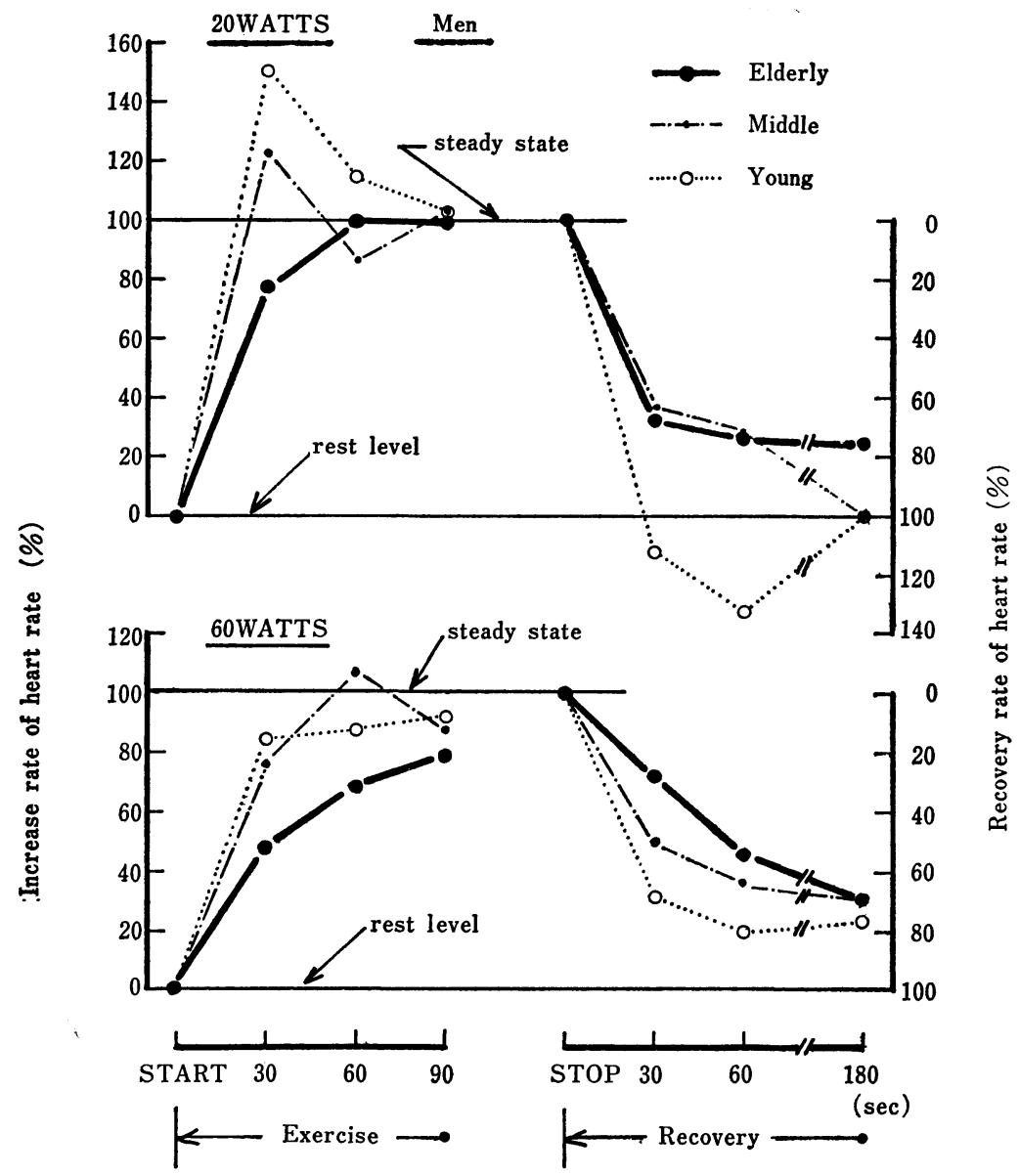

図 6 心拍数の初期上昇率および 回復率

Fig. 6 Increase and recovery rates of heart rate by different work loads. 
である．若年者の最大酸素脈は $12 \sim 17 \mathrm{ml} /$ beat 程度で あるが, 老化に伴い減少の傾向にあるとされている12). 酸素摄取量と心拍数の測定結果から酸素脈を算出した. 負荷が強くなると各年代とも酸素脈は増加の傾向を示し た. 20, 40 watts 負荷では年代差が認められないもの の, 60 watts 負荷で老年層の増加はほとんど止まり，乙 の負荷で老年層の酸素脈は若年, 壮年層に比較して有意 な低下（それぞれ $\mathrm{p}<0.01 ）$ を示した.とのととから $60 \mathrm{watts}$ 負荷の 段階で 老年層の 酸素脈は 最大酸素脈圏 内に相当接近していたと考えられる．60 watts 負荷が達 成できた老年男性は，対象とした老年男性15名中わずか に 7 名という結果からも，60 watts の作業強度が老年層 にとってかなりきつい作業であり，乙の達成率の低さは 酸素脈や最高血圧がそれぞれの許容水準の上限に接近し ていた裏づけとされよう。

\section{（3）心拍数初期上昇率および回復率（図 6)}

i ) 初期上昇率負荷が弱い場合, 若年, 壮年風は 作業開始30秒後で over shoot が観察され, 各年代とも 60 秒後には定常状態へ到達した。 しかし負荷が 60 watts と強くなると，作業開始から定常状態到達までの時間は 延長し, over shoot も認められない. 特に老年層の初 期上昇率は, すでに作業開始30秒後で若年, 壮年層に比 べて著しく低く，との 2 層と老年層の間には差（それぞ れ $\mathrm{p}<0.01)$ が検出された. 心拍数初期上昇率に年代差 が珰められたことは，老化に伴い筋労作に対して循環系 を支配する神経系の適応速度の遅延による影響と考えら れる(5).

ii ）回復率 20 watts 負荷終了から 30 秒を経過する と, 若年層はすでに安静水準まで到達するが, 老年風は 180秒後であっても回復がみられない. 60 watts 負荷で は年代差がさらに顕著となり，作業終了30秒後で老年， 壮年層間であっても差（ $\mathrm{p}<0.01 ）$ が検出された。

老年層でみられるこの回復率の低下は, 初期上昇率の 遅延による影響や，作業中の活動筋への酸素供給能力お よび筋組織自体の酸素受け入れ能力の低下により, 回復 期にもち越される酸素負債が増加した結果によるものと 推測される.

年代別に比較した心拍数初期上昇率および回復率の結 果から, 作業中に蓄積された酸素負債は若年, 壮年に比 較して老年層ははるかに多かったととが指摘される.乙 のととから， 60 watts 負荷で老年層の酸素捸取量の増加 が鈍化した理由のひとつは，酸素摂取量の反応が作業中 抑制された定常状態を持続し，分析にあたりこの抑制さ れた低い水準を老年層の 60 watts 負荷における反応值と して採用していたてとによる影響と考えられる.

\section{4. 考 察}

心拍数と血圧の関係について増田ら ${ }^{10)}$ は, 作業強度が 強くなれば中高年跲者は青年と比較して相対的に心拍数 の増加率より脈圧の増加率が高いととを指摘している. また, 温熱刺激としての気温の変化を若年者では心拍数 で，老年者は血圧の変化によって代償する傾向がみられ るととも報告9)されている. 作業量の増加により身体全 体の血流配分中で筋の占める割合は, 他の器官に比較し て著しい増大が認められる ${ }^{5)}$. 生理的許容範囲の狭い老 年層の場合, 日常生活で経験する程度の作業強度であっ ても, 筋血流量の増大を保障するためには，心拍数によ る増加以上に最高血圧の増高に多く比重をかける傾向が 読みとれ，増田らの報告を支持する結果が得られた。と りわけ老年層のなかでも作業能力が一段と低い女性にい たっては, 最高血圧とともに心拍数も著しく増加させな ければ活動筋への酸素補給の要求に応じきれないととが うかがわれ, 作業負荷に対する生理的反応は性差の影響 を強く受けつつ, 老化ととともに変化してゆくものと考 えられる.

60 watts 負荷で老年男性の酸素攝取量の増加速度が鈍 化した理由について，いくつかの測定指標による検討を 実施した. 心拍数と脈圧の積による心筇酸素捸取量の推 測結果からは, この負荷による老年㟄の反応が若年, 壮年層に比べて著しく高かったてとが認められ, 酸素攝 取量の反応結果と相反する内容を得た．また，老年層は 他の年代に比較して心拍数の初期上昇や回復に遅延の傾 向がみられ, 酸素運搬系に相当する循環機能の順応能, 予備能の減退や, 酸素消費系に当たる筋組織 内 $の$ 血 液 受け入れ能力の低下なども指摘された. 老年者の最大酸 素摂取量は若年者の 50 ～60\% と考えられ ${ }^{6)}, 70$ 歳平均 ではおよそ $25 \mathrm{ml} / \mathrm{kg} / \mathrm{min}$ となる. 最大酸素摂取量に対 する60 watts 負荷での酸素摂取量の割合を推定すると, 若年風は30〜 40\%であるのに対して，老年風は $60 \%$ 程度 も費やしているととになり，乙の負荷で占有される老年 層の酸素㩒取量は, 最大許容能力の水準に近い反応であ ったととが示唆される. この傾向は酸素脈，最高血圧の 結果からも読みとれ, 老年層はそれぞれの反応とも生理 的許容範囲の上限へかなり接近していたてとがうかがえ た。

これらの点から， 60 watts 負荷に対する老年層の酸素 摂取量の反応は， 5 分間という作業時間内で定常状態を 成立させるととに無理があったか, あるいはこの作業量 に対する酸素供給能力が循環機能の上限水準へ相当接近 
していたてとで，作業期間中を通して抑制された定常状 態が持続していたものと推測される．そしてての反応を 測定值として採用していたてとにより，老年層の酸素摂 取量の増加速度は鈍化した可能性が強いと考える。

\section{5. おわりに}

自転車エルゴメー夕負荷試験により, 日常生活で経験 する程度の作業量に対する循環機能の特徽を年代別, 性 別に分けて検討した. 老年女性の心拍数は40 watts の作 業強度で 145 拍に達し，標的心拍数を超える反応が記録 されたが，老年男性は60 watts の負荷であっても 110 拍 程度と女性に比へててかなり低い水準に止まり，心拍数の 反応結果だけに限れば，まだかなりの余裕力を残存して いるようにも思われた. しかし，ての作業量に対して心 拍数を除く他の測定指標は, 酸素摂取量の増加速度に減 少が認められるなど, 各指標とも生理的許容範囲の上限 に近い水準にあったてとがうかがわれ，老年男性に 60 watts 以上の作業強度を提示した場合に心拍数は急激な 増加を示すものと予測される.

ここで採用した複数の循環機能測定指標の結果から, およそ平均年秢が70歳であった老年層の作業遂行能力を 推測すると，日常活動の上限に相当する作業強度として 想定した 60 watts 負荷で 5 分間の持続を必要とする作業 量は, この年代の老年者にとって身体機能許容範囲の上 限に接近した作業水準であり，かなり強い負荷量であっ たと考えられる.

本研究は（財）高年齢者㕍用開発協会の助成のもとに “高年齢雇用者の学働適応能力に関する研究”（座長：野 呂影勇産業医科大学教授) の一部として行われた. こて に記して深謝する.

\section{参考文献}

1) Astrand, P.O. : Physical performance as a function of age, J. Amer. Med. Scand, 205(11), 729 733, 1968.

2) Borg, G. \& Linderholm, H. : Perceived exertion and pulse rate during graded exercise in various age groups, Acta. Med. Scand, 472, 37 42,
1972.

3） 中高年齢労働者ヘルスケア検討委員会：中高年粭 者の健康づくりに必要なヘルス・チェックに関する 試案の参考資料(3), 産業医学ジャーナル，3(6), 69 $\sim 79,1979$.

4）猪飼道夫：呼吸・循環機能からみた体力の限界, 呼吸之循環，16(6)，449４56, 1968.

5）猪飼道夫編著：身体運動の生理学， $94 ， 158$, 杏林 書院, 東京, 1973.

6）稲垣義明, 宇佐美暢久：エルゴメトリー, 62〜69, 新興医学, 東京, 1980 .

7）石井喜八：運動処方一最近の動向一,体育の科学, 28(10), 670 673, 1978.

8）加賀谷淳子, 石川芳子：主婦の生活時間構造と身 体活動水準, 体育の科学, 23, 796 803, 1973.

9）菊池安行, 坂本 弘, 佐藤方彦, 田中正敏, 吉田 敬一：生理人類学入門, 70 72, 南江堂, 東京, 1981.

10）増田 允, 芝山秀太郎, 江橋 博: 循環, 呼吸機 能の解析による中高年者の運動至適量の検索, 体力 研究, 6, 55 72, 1965.

11） Morehouse, L.E. （石井喜八，官下充正監訳）： 運動生理学実験法, 3 19, 217, 杏林書院, 東京, 1979.

12) Robinson, S., Dill, D.B., Tzankoff, S.P., Wagner, J.A. \& Robinson, R.D. : Longitudinal studies of aging in 37 men, J. Appl. Physiol., 38(2), 263 267, 1975.

13）佐藤陽彦, 福場良之, 井上 㸋, 安高 悟: 回復 期の生理的指標による動的筋作業の生理的負担の評 価, 人間工学, 16(2), 83 87, 1980 .

14) Shephard, R.J.: Human physiological work capacity, International biological programmer, 15, Cambridge university press, London, 1978.

15）徳田哲男：高齢者の運動時の生理的反応特性につ いて，自動車技術，35(5)，522 527， 1981.

16）朝長正徳：加数と筋・末梢神経系, 臨床成人病, 5(7), 721 731， 1975.

17）万木良平: Steady state exercise, 呼吸之循環, 16(6), 457 464, 1968. 